\title{
The cationic peptide magainin II is antimicrobial for Burkholderia cepacia-complex strains
}

\begin{abstract}
Correspondence
Helen S. Atkins

hsatkins@dstl.gov.uk
\end{abstract}

Received 19 November 2008

Accepted 11 March 2009

\author{
Joanne E. Thwaite, ${ }^{1}$ Suzanne Humphrey, ${ }^{1}$ Marc A. Fox, ${ }^{1}$ \\ Victoria L. Savage, ${ }^{1}$ Thomas R. Laws, ${ }^{1}$ David O. Ulaeto, ${ }^{1}$ \\ Richard W. Titball ${ }^{2}$ and Helen S. Atkins ${ }^{1}$ \\ ${ }^{1}$ Defence Science and Technology Laboratory, Porton Down, Salisbury SP4 OJO, UK \\ ${ }^{2}$ School of Biosciences, Geoffrey Pope Building, University of Exeter, Exeter EX4 4QD, UK
}

\begin{abstract}
This study was undertaken to determine the antibacterial activity of eight cationic antimicrobial peptides towards strains of genomovars I-V of the Burkholderia cepacia complex (Bcc) in timekill assays. All but one of the peptides failed to show activity against the panel of test strains. The exception was magainin II, a 23 aa peptide isolated from the epidermis of the African clawed frog, Xenopus laevis, which exhibited significant bactericidal activity for Bcc genomovars most frequently associated with lung infection of patients with cystic fibrosis. In vitro studies indicated that magainin II protected a human bronchial epithelial cell line (BEAS-2B) from killing by Bcc and suggest that this peptide may have therapeutic potential against these organisms.
\end{abstract}

\section{INTRODUCTION}

Organisms of the Burkholderia cepacia complex (Bcc) are associated with chronic opportunistic lung infections of patients suffering from cystic fibrosis (CF) and chronic granulomatous disease (Mahenthiralingam et al., 2000). Infections with Bcc are often coupled with a particularly poor prognosis, resulting in a rapid and fatal decline in pulmonary function due to necrotizing pneumonia and sepsis (Isles et al., 1984). This fatal decline in clinical condition has been termed 'cepacia syndrome' and has not been identified with any other CF-associated pathogen.

The Bcc comprises 15 distinct species formerly known as genomovars of B. cepacia (Vanlaere et al., 2008). Of these, the majority of infections in $\mathrm{CF}$ are attributed to Burkholderia multivorans and Burkholderia cenocepacia in both the UK and the USA (Mahenthiralingam et al., 2008; Reik et al., 2005), although all genomovars have been recovered from CF patients (Ortega et al., 2005). Eradication of an established Bcc infection is rarely achieved owing to the high intrinsic resistance of the genus to antimicrobial agents (Coenye et al., 2001). Although preventative strategies are considered the principal approach for management of Bcc infections (Jones \& Webb, 2003), combination therapy may be used, extending the spectrum of antimicrobial activity across multiple antibiotic classes (Bonacorsi et al., 1999).

Novel antimicrobial therapeutic agents are urgently required due to the threat of naturally resistant and

Abbreviations: Bcc, Burkholderia cepacia complex; CAMP, cationic antimicrobial peptide; CF, cystic fibrosis; LDH, lactate dehydrogenase. antibiotic-resistant strains. Cationic antimicrobial peptides (CAMPs) have potential, as they show broad-range activity against Gram-positive and Gram-negative bacteria, viruses and some fungal species (Hancock \& Lehrer, 1998). Importantly, these peptides do not present the same issue of resistance observed with conventional antibiotics (Zasloff, 2002) and often have good activity against several multidrug-resistant bacterial species (Giacometti et al., 2005a). There is also evidence that in vitro selection of CAMP-resistant mutants is difficult (Hancock \& Lehrer, 1998).

CAMPs are short, amphipathic, positively charged peptides that occur naturally in a wide range of species as vital components of the innate immune system and are also implicated in the adaptive immune response. The effects of CAMPs include antimicrobial activity (Zasloff, 2002), mast-cell degranulation (Niyonsaba et al., 2002), antiendotoxin activity (Bowdish et al., 2005) and enhanced pro-inflammatory responses (Lillard et al., 1999).

As previous reports have described B. cepacia as being resistant to the action of CAMPs (Denyer \& Maillard, 2002; Scott et al., 1999), we aimed to determine the efficacy of a panel of antimicrobial peptides against B. cepacia from genomovars I-V.

\section{METHODS}

Bacterial strains, growth conditions and media. The bacterial strains used in this study included 18 Bcc strains from genomovars I$\mathrm{V}$, which were originally provided by Professor John Govan (University of Edinburgh, Edinburgh, UK) and obtained from the culture collection at the Defence Science and Technology Laboratory 
(Dstl, Porton Down, Salisbury, UK). Representative strains for each genomovar comprised B. cepacia J2540 (genomovar I), B. multivorans 7897 (genomovar II), B. cenocepacia J2956 (genomovar III), Burkholderia stabilis 7639 (genomovar IV) and Burkholderia vietnamiensis LMG $10929^{\mathrm{T}}$ (genomovar V). All strains were handled in Advisory Committee for Dangerous Pathogens (ADCP) II containment facilities and were maintained on Luria-Bertoni (LB) agar plates or broth.

Antimicrobial agents. CAMPs were synthesized by Alta Biosciences (University of Birmingham, Birmingham, UK). The peptides tested comprised calcitermin (Cole et al., 2001), cecropin A (Holak et al., 1988), a granulysin fragment (Linde et al., 2005), LL-37 (Agerberth et al., 1995; Niyonsaba et al., 2002), MUC7 (Bobek \& Situ, 2003), P-113 (Giacometti et al., 2005b), ovine polyaspartic acid (Brogden et al., 1996) and magainin II (Giovannini et al., 1987; Zasloff, 1987). All of these are $\alpha$-helical peptides, with the exception of ovine polyaspartic acid, which is too small to determine any secondary structure (6 aa). Stock solutions were prepared by reconstituting each peptide in sterile PBS containing $0.02 \%$ acetic acid and $0.4 \%$ BSA (Sigma-Aldrich).

In vitro assays for antimicrobial activity. The antimicrobial activity of each CAMP was determined relative to a control containing no peptide using a modified microtitre broth dilution method (Steinberg et al., 1997). Liquid bacterial cultures were grown to mid-exponential phase and diluted to $1 \times 10^{5}$ c.f.u. $\mathrm{ml}^{-1}$.

Antibacterial time-kill assays. Strains were grown to midexponential phase in LB broth at $37^{\circ} \mathrm{C}$. Aliquots of these cultures containing approximately $1 \times 10^{8}$ c.f.u. $\mathrm{ml}^{-1}$ were exposed separately to PBS (control) or $128 \mu \mathrm{g}$ magainin II $\mathrm{ml}^{-1}$. Cultures were maintained at $37{ }^{\circ} \mathrm{C}$ with shaking (180 r.p.m.) throughout the assay. Samples were taken at $0,1,5,10,15,20,30,40,50,60,90,120,180$, 240 and $1440 \mathrm{~min}$ and then diluted serially in PBS and enumerated on LB agar. Viable counts (c.f.u. $\mathrm{ml}^{-1}$ ) were obtained after $18 \mathrm{~h}$ incubation at $37^{\circ} \mathrm{C}$.

Magainin II stability assay. Aliquots of magainin II were prepared at $256 \mu \mathrm{g} \mathrm{ml}^{-1}$ in LB broth and incubated at $37{ }^{\circ} \mathrm{C}$ for $0,2,5,24$ or $48 \mathrm{~h}$ prior to inoculation with a culture of B. cepacia J2540 grown to mid-exponential phase and containing approximately $1 \times 10^{8}$ c.f.u. $\mathrm{ml}^{-1}$. After inoculation, the concentration of magainin II in each sample was $128 \mu \mathrm{g} \mathrm{ml}^{-1}$; the control contained an equal volume of PBS. Samples were taken from the culture prior to inoculation into LB broth containing magainin II, and then at $30 \mathrm{~min}$ and at 1, 2, 3 and $4 \mathrm{~h}$ post-inoculation. These samples were serially diluted, plated onto LB agar and incubated at $37{ }^{\circ} \mathrm{C}$ for $18 \mathrm{~h}$ for viable counts. The decrease in c.f.u. $\mathrm{ml}^{-1}$ for each of the magainin II samples was compared with that produced by the freshly prepared peptide $(0 \mathrm{~h})$ to give an indication of the activity of magainin II following incubation over time, whilst a PBS control was used to measure normal B. cepacia growth over the $4 \mathrm{~h}$ period.

Effects of proteases on magainin II activity. B. cepacia J2450 was grown to late-stationary phase in $\mathrm{LB}$ broth at $37^{\circ} \mathrm{C}$ to allow maximal expression of extracellular proteases. Culture supernatant was passed through 0.45 and $0.2 \mu \mathrm{m}$ filters (Whatman International) to remove all bacteria. PBS (control), filtered culture supernatant or filtered culture supernatant + Complete ( 1 tablet in $50 \mathrm{ml}$ supernatant inhibits serine, metallo- and cysteine proteases; Roche Diagnostics) was added to magainin II at $102 \mu \mathrm{g} \mathrm{ml}^{-1}$ and incubated at $37{ }^{\circ} \mathrm{C}$ for $30 \mathrm{~min}$. These pre-treated magainin II peptides were used in a standard time-kill assay, and samples were taken and enumerated at $0,60,240,300,360$ and $1440 \mathrm{~min}$. To visualize the susceptibility of magainin II to proteases, $500 \mu \mathrm{g}$ magainin II ml ${ }^{-1}$ was incubated at $37{ }^{\circ} \mathrm{C}$ in supernatant from B. cepacia J2450 grown overnight in LB broth and filter-sterilized as above. Samples were removed at 0, 2, 5, 24 and $48 \mathrm{~h}$ and analysed by $4-20 \%$ Tris/glycine SDS-PAGE (Invitrogen) before staining with Coomassie blue.

In vitro cell protection assay. Apoptotic cell death was measured by the activity of the cytoplasmic enzyme lactate dehydrogenase (LDH), which is released into the culture supernatant following damage to the cytoplasmic membrane and so is proportional to cell death. A LDH ${ }^{\text {PLUS }}$ assay (Roche Diagnostics) was used to quantify the amount of $\mathrm{LDH}$ present and was performed in accordance with the manufacturer's instructions. Briefly, BEAS-2B human bronchial epithelial cells were cultured in Dulbecco's modified Eagle's medium (DMEM; Sigma-Aldrich) supplemented with $10 \%(\mathrm{v} / \mathrm{v})$ fetal calf serum (FCS; Sigma-Aldrich) at $37{ }^{\circ} \mathrm{C}$ with $5 \% \mathrm{CO}_{2}$. Cells were maintained as subconfluent monolayers, passaged by removal of the monolayer using DMEM culture medium and seeded into fresh polystyrene 96-well plates at $2 \times 10^{4}$ cells per well in a volume of $100 \mu \mathrm{l}$ and incubated for $16 \mathrm{~h}$. Cells were then incubated with magainin II across a concentration range of $25-200 \mu \mathrm{g} \mathrm{ml}^{-1}$ for $18 \mathrm{~h}$ at $37{ }^{\circ} \mathrm{C}$ with $5 \% \mathrm{CO}_{2}$. As a control to quantify maximal LDH release, cells were lysed with $1 \%(\mathrm{v} / \mathrm{v})$ Triton X-100 (Sigma-Aldrich) and incubated for $10 \mathrm{~min}$ at room temperature. To quantify normal LDH release, cells were cultured and incubated with PBS. Spectrophotometric measurement of formazan dye at $A_{450}$ was performed using a plate reader (EL800; BioTek Instruments). All tests were performed in triplicate with samples calculated as a percentage of the control (assuming $100 \%$ cytotoxicity), giving an indication of the reduction of $\mathrm{LDH}$ release.

Statistical analysis of data. Two-way analysis of variance followed by Bonferroni's post-tests were carried out using Graphpad Prism version 4.0. $P$ values $\leqslant 0.001$ were considered significant.

\section{RESULTS}

\section{Antimicrobial activity of peptides against Bcc strains}

Eight CAMPs were tested for inhibitory activity against 18 representative Bcc strains of genomovars $\mathrm{I}-\mathrm{V}$, and 50 and $90 \%$ inhibitory concentration values $\left(\mathrm{IC}_{50}\right.$ and $\mathrm{IC}_{90}$, respectively) were determined (Table 1). Subsequent experiments used the following strains as representative of each genomovar: B. cepacia J2540, genomovar I; $B$. multivorans 7897, genomovar II; B. cenocepacia J2956, genomovar III; B. stabilis 7639, genomovar IV; and B. vietnamiensis LMG $10929^{\mathrm{T}}$, genomovar V. Polymyxin B was used as a control antibiotic to which widespread antimicrobial resistance has frequently been described in $B$. cepacia species. Calcitermin, cecropin A, granulysin, LL-37, MUC-7, P113 and poly-D-aspartic acid showed no growth inhibitory activity at concentrations up to $256 \mu \mathrm{g} \mathrm{ml} \mathrm{m}^{-1}$ towards any of the Bcc strains tested. However, magainin II exhibited variable growth inhibitory activity towards Bcc strains and within genomovars at concentrations of 128 and $256 \mu \mathrm{g} \mathrm{ml} l^{-1}$, causing a reduction in the c.f.u. $\mathrm{ml}^{-1}$ of most strains when compared with controls. A possible exception was with genomovar $\mathrm{V}$ (B. vietnamiensis) where all strains exhibited $\mathrm{IC}_{50}$ values of $\geqslant 128 \mu \mathrm{g} \mathrm{ml} \mathrm{m}^{-1}$, suggesting marginally more magainin II resistance in this genomovar. 
Table 1. IC values of magainin II against Bcc strains

\begin{tabular}{|lcc|}
\hline Organism $^{*}$ & $\mathbf{I C}_{\mathbf{5 0}}\left(\boldsymbol{\mu} \mathbf{~} \mathbf{~ m l}^{-\mathbf{1}}\right)$ & $\mathbf{I C}_{\mathbf{9 0}}\left(\boldsymbol{\mu} \mathbf{g} \mathbf{~ m l}^{-\mathbf{1}}\right)$ \\
\hline B. cepacia $\mathrm{J} 2540$ & 128 & $>256 \dagger$ \\
B. cepacia 25416 & 8 & $>128$ \\
B. cepacia C2970 & 32 & $>128$ \\
B. cepacia 9091 & 32 & $>128$ \\
B. cepacia C1964 & 128 & $>128$ \\
B. multivorans 7897 & 16 & $>256 \dagger$ \\
B. multivorans ATCC 17616 & 128 & $>128$ \\
B. multivorans 7732 & $>128$ & $>128$ \\
B. cenocepacia J2956 & $>256 \dagger$ & $>256$ \\
B. cenocepacia J415 & $>128$ & $>128$ \\
B. cenocepacia C2836 & 32 & $>128$ \\
B. cenocepacia C1394 & 64 & $>128$ \\
B. stabilis 7639 & 32 & 64 \\
B. stabilis 14294 & 128 & $>128$ \\
B. stabilis 8088 & 64 & $>128$ \\
B. vietnamiensis LMG $10929^{\mathrm{T}}$ & $>256 \dagger$ & $>256 \dagger$ \\
B. vietnamiensis 549 & 128 & $>128$ \\
B. vietnamiensis C1709 & 128 & $>128$ \\
\hline
\end{tabular}

*Strains were tested in triplicate and analysed using a two-way analysis of variance.

$\dagger \mathrm{IC}_{50}>256 \mu \mathrm{g} \mathrm{ml}{ }^{-1}$ was considered to be resistant to magainin II.

\section{Temporal effect of magainin II towards Bcc strains}

In assays to evaluate the effect of magainin II over time, cultures of the five representative genomovar strains were incubated with $128 \mu \mathrm{g}$ magainin $\mathrm{II} \mathrm{ml}^{-1}$ and samples were collected at intervals between 0 and $1440 \mathrm{~min}$. Fig. 1 shows that magainin II exerted strong antimicrobial activity against genomovars I (B. cepacia J2540) and V (B. vietnamiensis LMG $10929^{\mathrm{T}}$ ). In each case, a reduction in c.f.u. $\mathrm{ml}^{-1}$ occurred within minutes of introducing the peptide to the culture at a concentration of $128 \mu \mathrm{g} \mathrm{ml}^{-1}$. Genomovar V was the most susceptible with complete killing after $10 \mathrm{~min}$, whilst the count of genomovar I was reduced by $2 \log _{10}$ within $5 \mathrm{~min}$. After this initial decrease, magainin II appeared to exhibit a bacteriostatic effect, maintaining viable counts at approximately $1 \times 10^{6}$ c.f.u. $\mathrm{ml}^{-1}$. By contrast, exposure of B. multivorans 7897 (genomovar II), B. cenocepacia J2956 (genomovar III) and B. stabilis 7639 (genomovar IV) to $128 \mu \mathrm{g}$ magainin II $\mathrm{ml}^{-1}$ did not result in an immediate decrease in bacterial number (data not shown). Instead, bacteriostatic activity towards these strains became evident at $40-120$ min postexposure, by which time growth of the control cultures had increased by almost $1 \log _{10}$, whilst the cultures exposed to peptide remained relatively constant. At $180 \mathrm{~min}$ postexposure to magainin II, genomovars II, III and IV were reduced by 35,20 and $85 \%$, respectively, of the initial c.f.u. $\mathrm{ml}^{-1}$ of the culture. All cultures, with the exception of $B$. vietnamiensis $\mathrm{LMG} 10929^{\mathrm{T}}$, exhibited regrowth to levels similar to that of controls after incubation at $37{ }^{\circ} \mathrm{C}$ for $24 \mathrm{~h}$

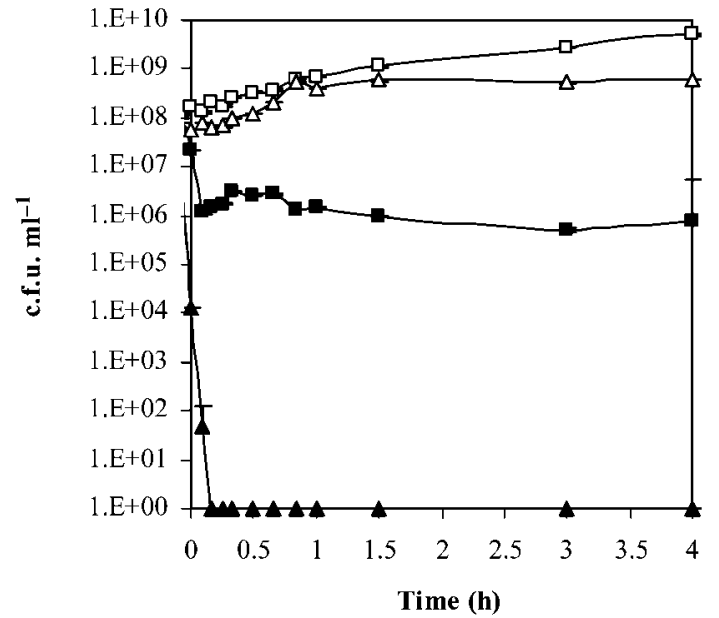

Fig. 1. Direct antimicrobial activity of $128 \mu \mathrm{g}$ magainin $\| \mathrm{ml}^{-1}$ against exponentially growing cultures of $B$. cepacia J2540 and $B$. vietnamiensis LMG $10929^{\top}$ over time. $\mathbf{\square}$, B. cepacia+128 $\mu \mathrm{g}$ magainin II ml ${ }^{-1} ; \square$, B. cepacia + PBS control; $\boldsymbol{\Delta}$, B. vietnamiensis $+128 \mu \mathrm{g}$ magainin II $\mathrm{ml}^{-1} ; \triangle, B$. vietnamiensis + PBS control. Error bars represent the SD of triplicate counts (c.f.u. $\mathrm{ml}^{-1}$ ).

with magainin II. This regrowth at the $24 \mathrm{~h}$ time point may account for the apparently high $\mathrm{IC}_{50}$ values determined for some genomovars and may mask the initial antimicrobial activity; resumption of bacterial growth at $24 \mathrm{~h}$ may be due to degradation of the peptide. The $\mathrm{IC}_{50}$ values therefore possibly underestimated the activity of magainin, with celldamaging effects being mediated at peptide concentrations lower than the $\mathrm{IC}_{50}$ concentrations.

\section{Stability of magainin II}

We hypothesized that the observed regrowth of bacteria after $24 \mathrm{~h}$ incubation with magainin II occurred because the peptide was unstable in solution, resulting in loss of antimicrobial activity. Thus $128 \mu \mathrm{g}$ magainin $\mathrm{II} \mathrm{ml}^{-1}$ was incubated in LB broth or bacterial culture supernatant for 0-48 h prior to exposure to B. cepacia J2540. Peptide activity was determined as a $2 \log _{10}$ decrease in viable bacteria. These experiments showed that some antimicrobial activity towards B. cepacia J2540 was retained following incubation for up to $24 \mathrm{~h}$ in culture supernatant (Fig. 2). Although the activity was reduced compared with that of the freshly prepared peptide, magainin II incubated for $24 \mathrm{~h}$ in culture supernatant resulted in a $1 \log$ decrease in viable bacteria compared with a $2 \log$ decrease seen with freshly prepared magainin II. All antimicrobial activity was lost following incubation for $48 \mathrm{~h}$ in culture supernatant.

\section{Effect of extracellular proteases on the antimicrobial activity of magainin II}

Several reports have indicated that bacterial proteases can confer resistance to antimicrobial peptides (Guina et al., 


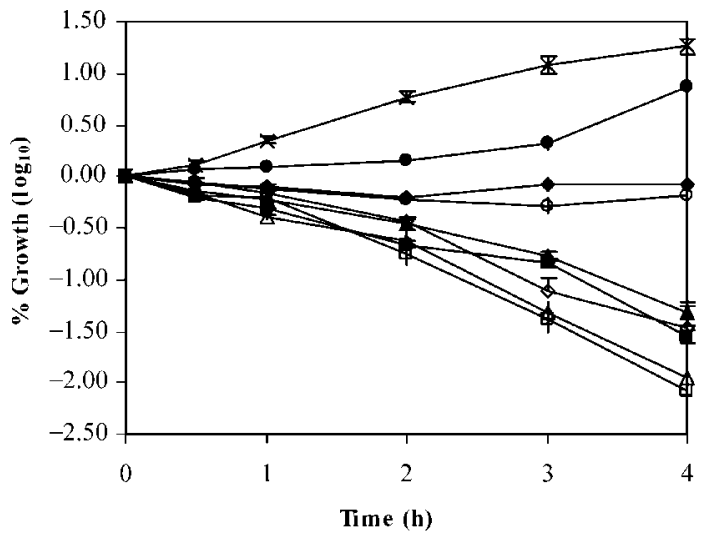

Fig. 2. Antimicrobial activity of $128 \mu \mathrm{g}$ magainin $\|^{-1} \mathrm{ml}^{-1}$ against $B$. cepacia J2540 incubated in bacterial culture supernatant or LB broth. Magainin II was incubated in B. cepacia J2540 filtersterilized culture supernatant or LB broth at $128 \mu \mathrm{g} \mathrm{ml}^{-1}$ for up to $48 \mathrm{~h}$ before use in antimicrobial assays for B. cepacia J2540. Results are shown for freshly prepared magainin II incubated in culture supernatant (filled symbols) or LB broth (unfilled symbols) at $0(\boldsymbol{\square}, \square), 2(\boldsymbol{\Lambda}, \triangle), 24(\diamond, \diamond)$ or $48(\bullet, \bigcirc)$ h prior to exposure with an exponentially growing culture of $B$. cepacia J2540. $\times$, PBS control. Error bars represent the SD from triplicate counts of c.f.u. $\mathrm{ml}^{-1}$.

2000; Park et al., 2001; Schmidtchen et al., 2002; Sieprawska-Lupa et al., 2004; Thwaite et al., 2006). To test whether this was true for Bcc strains, magainin II was incubated in the presence of filtered culture supernatant with and without a protease inhibitor for $30 \mathrm{~min}$ and then added to B. cepacia J2540 cells in broth. After incubation at $37^{\circ} \mathrm{C}$, the number of viable cells was determined at intervals up to $3 \mathrm{~h}$. Initial studies confirmed that the protease inhibitor alone did not affect the growth of the test strain (data not shown). In the absence of magainin II, B. cepacia J2540 grew over the course of the experiment (Fig. 3), and in the presence of magainin II in PBS the number of viable bacterial cells decreased. The rate of decrease of viable cell numbers was slowed when magainin II was pre-incubated with culture supernatant, but preincubation of the peptide with culture supernatant containing protease inhibitors restored the killing activity of the peptide $(P<0.0001)$. To confirm the degradation of magainin II by proteases, samples of the peptide incubated in B. cepacia J2540 culture supernatant for up to $48 \mathrm{~h}$ were analysed by SDS-PAGE. At $48 \mathrm{~h}$, magainin II could no longer be visualized by Coomassie blue staining (Fig. 4), indicating its digestion by proteases present in the supernatant.

\section{Magainin II decreases LDH release from BEAS-2B cells in response to $B$. cepacia infection}

As previous reports have shown that magainin II has substantial anti-cancer properties (Ohsaki et al., 1992), the

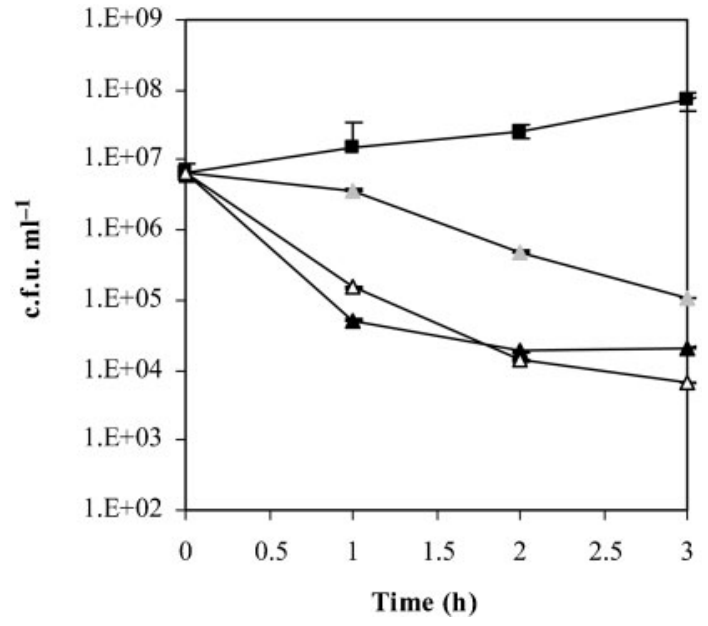

Fig. 3. Antimicrobial activity of magainin II against $B$. cepacia $\mathrm{J} 2540$ in the presence of protease. Magainin II was pre-treated in filtered B. cepacia J2540 culture supernatant (grey triangle) or in filtered B. cepacia J2540 culture supernatant + Complete protease inhibitor $(\triangle)$ or left untreated $(\boldsymbol{\Delta})$ and then evaluated for its activity against $B$. cepacia J2540. - , PBS control. The error bars represent the SD calculated from five individual samples.

non-cancerous human bronchial epithelial cell line BEAS$2 \mathrm{~B}$ was used to evaluate the antimicrobial effects of the peptide towards Bcc strains in cell culture. LDH release from infected cells was used as a measure of cell-membrane damage and loss of cell integrity. Exposure of BEAS-2B cells to the representative strain panel of the Bcc resulted in release of LDH into cell culture medium compared with control cells. The addition of magainin II to the cell culture to a concentration of $25-200 \mu \mathrm{g} \mathrm{ml}^{-1}$ and subsequent

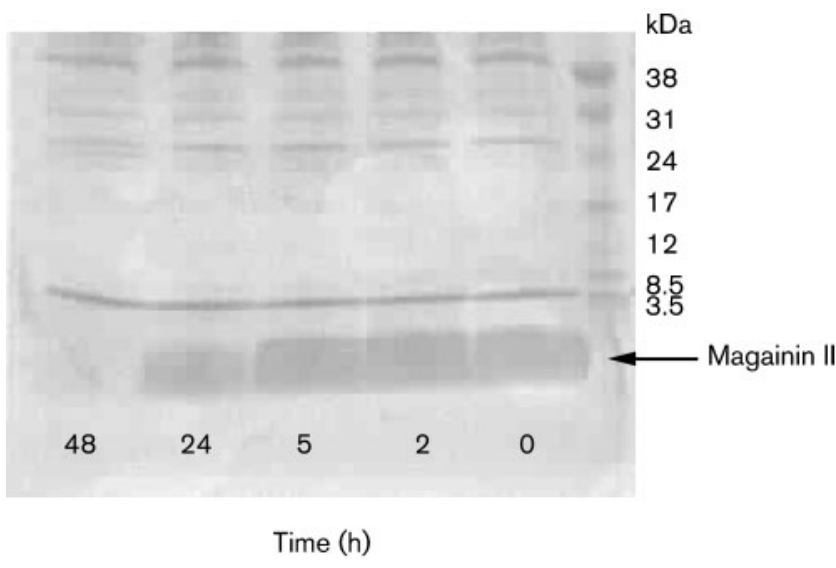

Fig. 4. Persistence of magainin II in $B$. cepacia culture supernatant. Magainin II (500 $\left.\mu \mathrm{g} \mathrm{ml}^{-1}\right)$ was incubated in B. cepacia J2540 culture supernatant for up to $48 \mathrm{~h}$ to determine its susceptibility to protease digestion. The presence of magainin II was visualized by SDS-PAGE and staining with Coomassie blue. 
Table 2. Protection afforded to BEAS-2B cells by magainin II against Bcc infection

All values represent triplicate samples.

\begin{tabular}{|c|c|c|c|c|c|c|c|}
\hline & \multirow[t]{2}{*}{$\mathrm{LDH}$ released $\left(\mu \mathrm{g} \mathrm{ml}^{-1}\right)$} & \multicolumn{6}{|c|}{$\begin{array}{l}\text { LDH released }(\%)^{\star} \text { at a peptide concentration } \\
\qquad\left(\mu \mathrm{g} \mathrm{ml}^{-1}\right) \text { of: }\end{array}$} \\
\hline & & $\mathbf{0}$ & 25 & 50 & 100 & 150 & 200 \\
\hline Background control $\dagger$ & 2.88 & 0 & 0 & 3 & 9 & 15 & 33 \\
\hline Lysis controlł & 41.50 & 100 & 100 & 100 & 100 & 100 & 100 \\
\hline B. серасіа $\mathrm{J} 2540$ & & 100 & 100 & 99 & 58 & 0 & 0 \\
\hline B. multivorans 7897 & & 100 & 100 & 100 & 86 & 6 & 0 \\
\hline B. сепосерасіа J2956 & & 100 & 100 & 93 & 86 & 78 & 80 \\
\hline B. stabilis 7639 & & 100 & 84 & 83 & 72 & 3 & 0 \\
\hline B. vietnamiensis $\mathrm{LMG} 10929^{\mathrm{T}}$ & & 100 & 14 & 1 & 0 & 0 & 0 \\
\hline
\end{tabular}

${ }^{\star} \mathrm{LDH}$ released above the background control as a percentage of total cell lysis with Triton X-100.

$\dagger$ Background lysis control: no magainin II or bacteria.

\$Positive control: complete cell lysis with Triton X-100.

infection with the strains reduced the level of LDH release (Table 2). The degree of protection of BEAS-2B cells from lysis by B. cepacia was measured as the percentage of $\mathrm{LDH}$ released compared with the total $\mathrm{LDH}$ released after Triton $\mathrm{X}-100$ lysis of the cells. This indicated that $200 \mu \mathrm{g}$ magainin II $\mathrm{ml}^{-1}$ conferred complete protection to the cells from infection with $B$. cepacia J2540, but only $20 \%$ protection against B. cenocepacia J2956. However, the peptide offered some protection against infection by all five genomovar strains.

\section{DISCUSSION}

This study describes an evaluation of the antimicrobial potential of several CAMPs against strains of the B. cepacia complex, with the ultimate aim of developing a more efficacious treatment for infections with these organisms. From the panel of antimicrobial peptides analysed, we have reported the novel finding that only magainin II showed moderate activity against Bcc genomovars I-V.

Magainins are broad-spectrum, positively charged, antimicrobial peptides that are secreted constitutively from the skin of the African clawed frog (Xenopus laevis) onto the epithelial surface (Zasloff, 1987). These 23 aa peptides exhibit antibacterial, antiviral, antifungal and tumoricidal properties and are considered an essential facet of the innate immune system in preventing infection. Magainin II has previously been described to exert antimicrobial activity against multidrug-resistant bacteria such as meticillin-resistant Staphylococcus aureus, Pseudomonas aeruginosa (Giacometti et al., 2005a) and Stenotrophomonas maltophilia (Giacometti et al., 2000) and against some viruses including herpes simplex virus types 1 and 2 (Albiol Matanic \& Castilla, 2004). We determined that magainin II was the only antimicrobial peptide tested in this study that exerted activity against selected strains of the Bcc. It was bacteriostatic for representative strains of genomovars I, II, III and IV and bactericidal for genomovar V. The strain-to-strain differences observed in $\mathrm{IC}_{50}$ values for magainin II within the Bcc may be a consequence of the extreme genetic diversity within the Bcc group. The large $(\sim 8 \mathrm{Mb})$ genome is carried on multiple replicons, which may add greater flexibility in the acquisition, loss and expression of genes (Lessie et al., 1996; Mahenthiralingam \& Drevinek, 2007).

Owing to the direct antimicrobial activity of CAMPs on the bacterial membrane, acquisition of resistance to these peptides is unlikely considering the highly conserved structure of the target molecule (Hancock \& Lehrer, 1998; Matsuzaki et al., 1995). Furthermore, the selection of resistant organisms within a bacterial population would be unlikely because of the rapid and broad-spectrum activity of the peptides and the high metabolic burden of membrane alteration (Hancock \& Scott, 2000; Zasloff, 2002). Pathogens exhibiting natural resistance against antimicrobial peptides utilize a range of strategies to render the peptides less effective (Ganz, 2001). Here, we showed that Bcc species produce extracellular proteases that are capable of degrading antimicrobial peptides, a characteristic also described in a number of other pathogens (Schmidtchen et al., 2002; Thwaite et al., 2006). We found that magainin II was unstable at $37{ }^{\circ} \mathrm{C}$ in LB broth or culture supernatant, leading to compromised antimicrobial activity. This problem may be ameliorated by the synthesis of magainin II derivatives containing $\mathrm{D}$-amino acids (Bessalle et al., 1990) or $\beta$ peptides (Frackenpohl et al., 2001) or the use of nonpeptidic antibiotic CAMP mimics (Tew et al., 2006) to provide more stable antimicrobial compounds. Stabilization of magainin II may therefore reduce enzymic degradation and increase the potency of the peptide. Indeed, novel therapeutic compounds based on magainin II are currently under development to maximize activity and decrease proteolytic sensitivity (Fuchs et al., 1998; 
Gottler \& Ramamoorthy, 2008). Magainin II can be used for topical application (Chopra, 1993), but to date has not been evaluated as a nebulized agent for delivery into the lungs of CF patients.

Recent observations have indicated that magainin II acts synergistically with several antibiotics including piperacillin, ceftazidime, imipenem, meropenem, clarithromycin and polymyxin E (Giacometti et al., 2000). A synergistic action with ceftazidime, one of the few antibiotics of choice for treatment of Bcc infections (Rajyaguru \& Muszynski, 1997), may be advantageous for a combinational treatment, with the peptide reducing the initial bacterial load and perhaps providing an extended window for antibiotic treatment or possibly enhancing the efficacy of the antibiotic.

Despite the range of virulence factors conferring resistance to antimicrobial peptides, we have shown that magainin II retains moderate antimicrobial activity against Bcc strains in vitro. Further studies are required to determine the utility of the peptide in vivo. However, this peptide has potential advantages over classical antibiotics as an antimicrobial with rapid, broad-spectrum activity and potentially fewer problems associated with resistance.

\section{ACKNOWLEDGEMENTS}

This work was performed with funding from the UK Ministry of Defence. Published with the permission of the Defence Science and Technology Laboratory on behalf of the Controller of HMSO.

\section{REFERENCES}

Agerberth, B., Gunne, J., Odeberg, P., Kogner, H., Boman, H. G. \& Gudmundsson, G. H. (1995). FALL-39, a putative human peptide antibiotic, is cysteine-free and expressed in bone marrow and testis. Proc Natl Acad Sci U S A 92, 195-199.

Albiol Matanic, V. C. \& Castilla, V. (2004). Antiviral activity of antimicrobial cationic peptides against Junin virus and herpes simplex virus. Int J Antimicrob Agents 23, 382-389.

Bessalle, R., Kapitkovsky, A., Gorea, A., Shalit, I. \& Fridkin, M. (1990). All-D-magainin: chirality, antimicrobial activity and proteolytic resistance. FEBS Lett 274, 151-155.

Bobek, L. A. \& Situ, H. (2003). MUC7 20-mer: investigation of antimicrobial activity, secondary structure, and possible mechanism of antifungal action. Antimicrob Agents Chemother 47, 643-652.

Bonacorsi, S., Fitoussi, F., Lhopital, S. \& Bingen, B. (1999). Comparative in vitro activities of meropenem, imipenem, temocillin, piperacillin, and ceftazidime in combination with tobramycin, rifampin, or ciprofloxacin against Burkholderia cepacia isolates from patients with cystic fibrosis. Antimicrob Agents Chemother 43, 213217.

Bowdish, D. M., Davidson, D. J., Scott, M. G. \& Hancock, R. E. W. (2005). Immunomodulatory activities of small host defense peptides. Antimicrob Agents Chemother 49, 1727-1732.

Brogden, K. A., de Lucca, A. J., Bland, J. \& Elliott, S. (1996). Isolation of an ovine pulmonary surfactant-associated peptide bactericidal for Pasteurella haemolytica. Proc Natl Acad Sci U S A 93, 412-416.

Chopra, I. (1993). The magainins: antimicrobial peptides with potential for topical application. J Antimicrob Chemother 32, 351-353.
Coenye, T., Vandamme, P., Govan, J. R. W. \& Lipuma, J. J. (2001). Taxonomy and identification of the Burkholderia cepacia complex. J Clin Microbiol 39, 3427-3436.

Cole, A. M., Kim, Y. H., Tahk, S., Hong, T., Weis, P., Waring, A. J. \& Ganz, T. (2001). Calcitermin, a novel antimicrobial peptide isolated from human airway secretions. FEBS Lett 504, 5-10.

Denyer, S. P. \& Maillard, J. Y. (2002). Cellular impermeability and uptake of biocides and antibiotics in Gram-negative bacteria. $J$ Appl Microbiol 92, 35S-45S.

Frackenpohl, J., Arvidsson, P. I., Schreiber, J. V. \& Seebach, D. (2001). The outstanding biological stability of $\beta$ - and $\gamma$-peptides towards proteolytic enzymes: an in vitro investigation with fifteen peptidases. ChemBioChem 2, 445-455.

Fuchs, P. C., Barry, A. L. \& Brown, S. D. (1998). In vitro antimicrobial activity of MSI-78, a magainin analog. Antimicrob Agents Chemother 42, 1213-1216.

Ganz, T. (2001). Fatal attraction evaded: how pathogenic bacteria resist cationic polypeptides. J Exp Med 193, F31-F33.

Giacometti, A., Cirioni, O., Prete, M. S., Barchiesi, F., Fortuna, M., Drenaggi, D. \& Scalise, G. (2000). In vitro activities of membraneactive peptides alone and in combination with clinically used antimicrobial agents against Stenotrophomonas maltophilia. Antimicrob Agents Chemother 44, 1716-1719.

Giacometti, A., Cirioni, O., Kamysz, W., Silvestri, C., Licci, A., Riva, A., Lukasiak, J. \& Scalise, G. (2005a). In vitro activity of amphibian peptides alone and in combination with antimicrobial agents against multidrug-resistant pathogens isolated from surgical wound infection. Peptides 26, 2111-2116.

Giacometti, A., Cirioni, O., Kamysz, W., D’Amato, G., Silvestri, C., Del Prete, M. S., Licci, A., Riva, A., Lukasiak, J. \& Scalise, G. (2005b). In vitro activity of the histatin derivative $\mathrm{P}-113$ against multidrugresistant pathogens responsible for pneumonia in immunocompromised patients. Antimicrob Agents Chemother 49, 1249-1252.

Giovannini, M. G., Poulter, L., Gibson, B. W. \& Williams, D. H. (1987). Biosynthesis and degradation of peptides derived from Xenopus laevis prohormones. Biochem J 243, 113-120.

Gottler, L. M. \& Ramamoorthy, A. (2008). Structure, membrane orientation, mechanism, and function of pexiganan - a highly potent antimicrobial peptide designed from magainin. Biochim Biophys Acta, (Epub ahead of print) doi:10.1016/j.bbamem. 2008.10.009

Guina, T., Yi, E. C., Wang, H. L., Hackett, M. \& Miller, S. I. (2000). A PhoP-regulated outer membrane protease of Salmonella enterica serovar Typhimurim promotes resistance to $\alpha$-helical antimicrobial peptides. J Bacteriol 182, 4077-4086.

Hancock, R. E. W. \& Lehrer, R. (1998). Cationic peptides: a new source of antibiotics. Trends Biotechnol 16, 82-88.

Hancock, R. E. W. \& Scott, M. G. (2000). The role of antimicrobial peptides in animal defenses. Proc Natl Acad Sci U S A 97, 8856-8861.

Holak, T. A., Engstroem, A., Kraulis, P. J., Lindeberg, G., Bennich, H., Jones, T. A., Gronenborn, A. M. \& Clore, G. M. (1988). The solution conformation of the antibacterial peptide cecropin A: a nuclear magnetic resonance and dynamical simulated annealing study. Biochemistry 27, 7620-7629.

Isles, A., Maclusky, I., Corey, M., Gold, R., Prober, C., Fleming, P. \& Levison, H. (1984). Pseudomonas cepacia infection in cystic fibrosis: an emerging problem. J Pediatr 104, 206-210.

Jones, A. M. \& Webb, A. K. (2003). Recent advances in cross infection in cystic fibrosis: Burkholderia cepacia complex, Pseudomonas aeruginosa, MRSA and Pandorea spp. J R Soc Med 96 (Suppl. 43), 66-72. 
Lessie, T. G., Hendrickson, W., Manning, B. D. \& Devereux, R. (1996). Genomic complexity and plasticity of Burkholderia cepacia. FEMS Microbiol Lett 144, 117-128.

Lillard, J. W., Jr, Boyaka, P. N., Chertov, O., Oppenheim, J. J. \& McGhee, J. R. (1999). The role of antimicrobial peptides in innate immunity. Proc Natl Acad Sci U S A 96, 651-656.

Linde, C. M., Grundström, S., Nordling, E., Refai, E., Brennan, P. J. \& Andersson, M. (2005). Conserved structure and function in the granulysin and NK-lysin peptide family. Infect Immun 73, 6332-6339.

Mahenthiralingam, E. \& Drevinek, P. (2007). Comparative genomics of Burkholderia species. In Burkholderia: Molecular Biology and Genomics. Edited by T. Coenye \& P. Vandamme. Norwich, UK: Horizon Scientific Press.

Mahenthiralingam, E., Coenye, T., Chung, J. W., Speert, D. P., Govan, J. R. W., Taylor, P. \& Vandamme, P. (2000). Diagnostically and experimentally useful panel of strains from the Burkholderia cepacia complex. J Clin Microbiol 38, 910-913.

Mahenthiralingam, E., Baldwin, A. \& Dowson, C. G. (2008). Burkholderia cepacia complex bacteria: opportunistic pathogens with important natural biology. J Appl Microbiol 104, 1539-1551.

Matsuzaki, K., Sugishita, K., Fujii, N. \& Miyajima, K. (1995). Molecular basis for membrane selectivity of an antimicrobial peptide, magainin 2. Biochemistry 34, 3423-3429.

Niyonsaba, F., Iwabuchi, A., Someya, A., Hirata, M., Matsuda, H., Ogawa, H. \& Nagaoka, I. (2002). A cathelicidin family of human antibacterial peptide LL-37 induces mast cell chemotaxis. Immunology 106, 20-26.

Ohsaki, Y., Gazdar, A. F., Chen, H. C. \& Johnson, B. E. (1992). Antitumor activity of magainin analogues against human lung cancer cell lines. Cancer Res 52, 3534-3538.

Ortega, X., Hunt, T. A., Loutet, S., Vinion-Dubiel, A. D., Dutta, A., Choudhury, B., Goldberg, J. B., Carlson, R. \& Valvano, M. A. (2005). Reconstitution of $O$-specific lipopolysaccharide expression in Burkholderia cenocepacia strain $\mathrm{J} 2315$, which is associated with transmissible infections in patients with cystic fibrosis. $J$ Bacteriol 187, 1324-1333.

Park, P. W., Pier, G. B., Hinkes, M. T. \& Bernfield, M. (2001). Exploitation of syndecan-1 shedding by Pseudomonas aeruginosa enhances virulence. Nature 411, 98-102.
Rajyaguru, J. M. \& Muszynski, M. J. (1997). Enhancement of Burkholderia cepacia antimicrobial susceptibility by cationic compounds. J Antimicrob Chemother 40, 345-351.

Reik, R., Spilker, T. \& Lipuma, J. J. (2005). Distribution of Burkholderia cepacia complex species among isolates recovered from persons with or without cystic fibrosis. J Clin Microbiol 43, 29262928.

Schmidtchen, A., Frick, I. M., Andersson, E., Tapper, H. \& Björck, L. (2002). Proteinases of common pathogenic bacteria degrade and inactivate the antibacterial peptide LL-37. Mol Microbiol 46, 157-168.

Scott, M. G., Yan, H. \& Hancock, R. E. W. (1999). Biological properties of structurally related $\alpha$-helical cationic antimicrobial peptides. Infect Immun 67, 2005-2009.

Sieprawska-Lupa, M., Mydel, P., Krawczyk, K., Wojcik, K., Puklo, M., Lupa, B., Suder, P., Silberring, J., Reed, M. \& other authors (2004). Degradation of human antimicrobial peptide LL-37 by Staphylococcus aureus-derived proteinases. Antimicrob Agents Chemother 48, 4673-4679.

Steinberg, D. A., Hurst, M. A., Fujii, C. A., Kung, A. H., Ho, J. F., Cheng, F. C., Loury, D. J. \& Fiddes, J. C. (1997). Protegrin-1: a broad spectrum, rapidly microbicidal peptide with in vivo activity. Antimicrob Agents Chemother 41, 1738-1742.

Tew, G. N., Clements, D., Tang, H. Z., Arnt, L. \& Scott, R. W. (2006). Antimicrobial activity of an abiotic host defense peptide mimic. Biochim Biophys Acta 1758, 1387-1392.

Thwaite, J. E., Hibbs, S., Titball, R. W. \& Atkins, T. P. (2006). Proteolytic degradation of the human antimicrobial peptide LL-37 by Bacillus anthracis may contribute to virulence. Antimicrob Agents Chemother 50, 2316-2322.

Vanlaere, E., Lipuma, J. J., Baldwin, A., Henry, D., De Brandt, E., Mahenthiralingam, E., Speert, D., Dowson, C. \& Vandamme, P. (2008). Burkholderia latens sp. nov., Burkholderia diffusa sp. nov., Burkholderia arboris sp. nov., Burkholderia seminalis sp. nov. and Burkholderia metallica sp. nov., novel species within the Burkholderia cepacia complex. Int J Syst Evol Microbiol 58, 1580-1590.

Zasloff, M. (1987). Magainins, a class of antimicrobial peptides from Xenopus skin: isolation, characterization of two active forms, and partial cDNA sequence of a precursor. Proc Natl Acad Sci U S A 84, 5449-5453.

Zasloff, M. (2002). Antimicrobial peptides of multicellular organisms. Nature 415, 389-395. 